\title{
SPAWNING PERFORMANCE OF NATIVE THREATENED SPOTTED SNAKEHEAD FISH, CHANNA PUNCTATUS (ACTINOPTERYGII: CHANNIDAE: PERCIFORMES), INDUCED WITH OVATIDE
}

\author{
Kasi MARIMUTHU ${ }^{1 *}$, Mohammed A. HANIFFA ${ }^{2}$, and Mohammad AMINUR RAHMAN ${ }^{3}$ \\ ${ }^{1}$ Department of Biotechnology, AIMST University, Bedong, Kedah Darul Aman, Malaysia \\ ${ }^{2}$ Centre for Aquaculture Research and Extension, (CARE) St. Xavier's College, Palayamkottai - 627002, \\ Tamilnadu, India \\ ${ }^{3}$ Smithsonian Tropical Research Institute (STRI) Box 0843-03092 Naos Island, Balboa Republic of Panama
}

Marimuthu K., Haniffa M.A., Aminur Rahman M. 2009. Spawning performance of native threatened spotted snakehead fish, Channa punctatus (Actinopterygii: Channidae: Perciformes), induced with Ovatide. Acta Ichthyol. Piscat. 39 (1): 1-5.

\begin{abstract}
Background. The spotted snakehead, Channa punctatus is a highly priced freshwater food fish species in India. The culture of snakeheads is still not common due to the scarcity of quality seed supply and lack of knowledge on their feeding and breeding techniques. Therefore an experiment was conducted to test the efficacy of a new spawning agent, Ovatide in stimulating ovulation of snakehead fish under a controlled captive condition.

Materials and Methods. In total, 12 matured females and 24 male fish weighing 50-90 g were randomly selected for three hormonal treatment groups and one control group. Both male and female fish in each treatment group were administered with either saline $(0.9 \% \mathrm{NaCl}$, control group), or $0.2,0.4$, and $0.6 \mathrm{~mL}$ of Ovatide per $\mathrm{kg}$ of body weight (BW), respectively. Each breeding set consisted of two males and one female. The hormone-treated fish were then held in concrete tanks for spawning. The breeding performance was evaluated based on spawning fecundity, spawning response, percentage fertilization, and percentage hatching.

Results. No spawning behaviour or performance was observed in control group. Partial spawning was observed with the Ovatide dose of $0.2 \mathrm{~mL} \cdot \mathrm{kg}^{-1} \mathrm{BW}$, and complete spawning was noticed in the medium Ovatide dose $\left(0.4 \mathrm{~mL} \cdot \mathrm{kg}^{-1} \mathrm{BW}\right)$, and the higher dose $\left(0.6 \mathrm{~mL} \cdot \mathrm{kg}^{-1} \mathrm{BW}\right)$ administered fish. The highest total spawning fecundity $(P<0.05)$ was recorded when the females were injected with $0.4 \mathrm{~mL}$ of Ovatide $\cdot \mathrm{kg}^{-1} \mathrm{BW}$ than those injected with other doses. The latency period and the number of spawned eggs were ranged from 25 to $31 \mathrm{~h}$ and from 1080 to 5814 , respectively. The highest fertilization- $(90.6 \%)$ and hatching $(91.33 \%)$ rates were also observed at the medium dose $(P<0.05)$. With regard to hatching rates, no significant difference was noticed between the medium- and higher doses of Ovatide-treated groups.

Conclusions. The synthetic gonadotropin-releasing hormone with a dopamine antagonist at the dose of $0.4 \mathrm{~mL} \cdot \mathrm{kg}^{-1}$ BW could be used as an appropriate stimulating agent for successful spawning and induced breeding of C. punctatus under captive conditions.
\end{abstract}

Keywords: Snakehead, Channa punctatus, hormones, induced spawning, seed production, conservation

\section{INTRODUCTION}

The single most important drawback of large-scale commercial culture of several fish species is the deficiency of quality seed of uniform size, and free of diseases, parasites, and pests at the time of stocking in culture ponds. These strict requisites are seldom fulfilled where the seed is obtained from the natural water bodies (Zohar and Mylonas 2001). Furthermore, the broodfish that are obtained from the wild and taken to captivity or reared in captive conditions may receive inappropriate environ- mental cues for reproduction and these can cause reproductive development to be arrested in late vitellogenesis. For this reason, hormonal treatment been attempted for stimulating of gametes maturation and have been successfully used to spawn many commercially important fish species that exhibit arrested reproductive development (Zohar and Mylonas 2001).

It is well known that reproductive processes in fishes are controlled by endogenous biological rhythms as well as by environmental cues (Munro 1990). Endogenous

\footnotetext{
* Correspondence: Dr. Kasi Marimuthu, Department of Biotechnology, Faculty of Applied Sciences, AIMST University, Batu 3 1/2 Bukit Air Nasi, Jalan Bedong Semeling 08100 Bedong, Kedah Darul Aman, Malaysia, phone: 00604-429 8000, fax: 00604-429 8009, e-mail:aquamuthu2k@yahoo.com
} 
control is mediated through actions of various hormones along the brain-hypothalamus-pituitary-gonad axis. Under natural conditions environmental stimuli are detected and relayed to the brain, resulting in a release of hormones and neurotransmitters that regulate ovulation (Yaron 1995, Peter and Yu 1997). The most important reproductive hormone is gonadotropin-releasing hormone $(\mathrm{GnRH})$ that regulates gonadotropic hormone, GtH (Peter and $\mathrm{Yu}$ 1997). Gonadotropin release in teleost fishes is also influenced by a gonadotropin-inhibiting factor (GRIF) from the hypothalamus. This factor has been identified as dopamine and demonstrated to have inhibitory activity on the release of GtH (Peter et al. 1988). Several commercially available synthetic ovulating agents in ready made form containing GnRHa and dopamine antagonist like Ovaprim, Ovopel, Dagin, and Aquaspawn are becoming very popular nowadays and found to be efficient and successful spawning agent in different fish species (Peter et al. 1988, Cheah and Lee 2000, Das 2004, Brzuska 2001, 2003, 2006). Ovatide, a new ovulating agent has successfully been tested by the Central Institute of Fisheries Education (ICAR), Mumbai including some other parts of India since 1997. Ovatide, a readily injectable spawning agent inducing gonadotropic hormone, consisting of $\mathrm{GnRH}$ analogue and dopamine antagonist, is also found to be efficient in induced spawning (Sahoo et al. 2005, Marimuthu et al. 2000, 2007). Recently Ovatide has been used to induce spawning in stinging catfish, Heteropneustes fossilis (cf. Marimuthu et al. 2000); snakehead murrel, Channa striatus (cf. Marimuthu et al. 2007); and in walking catfish, Clarias batrachus (cf. Sahoo et al. 2005).

The spotted snakehead, Channa punctatus (Bloch, 1793), is locally known as spotted murrel and one among the highly priced freshwater food fish species in India. It is found to be distributed throughout the South East Asian countries and has been identified as a potential candidate species for aquaculture in derelict and swampy water as it is a hardy and an air-breathing fish. The fish is well known for its taste, high protein content and low intramuscular spines, high nutritive value, recuperative and medicinal qualities, and is recommended as a diet during convalescence (Haniffa et al. 2004). Over the last 10 years, its wild population has undergone a steady decline due to overexploitation, loss of habitat, introduction of alien species, disease, pollution, siltation, poisoning, dynamite, and destructive fishing. These factors not only destroyed the feeding and breeding grounds but also caused havoc to the biodiversity of this important fishery. As a result, according to IUCN status (Molur and Walker 1998), it has been listed among the 66 low-risk nearthreatened fish species in India. Information on the induction of spawning and artificial propagation of C. punctatus is limited (Parameshwaran and Murugesan 1976). Therefore, the present study was attempted to investigate the efficacy of a synthetic GnRH, with a dopamine antagonist for the induction of ovulation and the initiation of spawning in C. punctatus, and to determine the minimum effective dose of Ovatide that could be used to spawn and produce seed of the candidate fish species under a controlled captive condition.

\section{MATERIALS AND METHODS}

Broodfish, weighing from 50 to $90 \mathrm{~g}$, were maintained in earthen ponds $(3 \times 3 \times 1 \mathrm{~m})$ at the Centre for Aquaculture Research and Extension (CARE), Palayamkottai, Tamilnadu, India. The fish were fed cleaned chicken viscera ad libitum daily for their normal growth and gonadal development. Mature male fish was identified by a slightly pointed genital papilla, and mature females by a swollen abdomen and a reddish, swollen vent (Haniffa et al. 1996). In addition, maturity of the female was confirmed by slightly pressing along the ventral side of the fish for oozing of eggs. A sample of 10-20 eggs from each female was collected by hand stripping and immersed in a solution containing $70 \%$ acetic acid and $30 \%$ ethanol for clarification of the cytoplasm. About 3 min subsequent to immersion, the position of the oocyte nuclei was determined. Migration of the nucleus from the centre of eggs to its periphery indicates the readiness of fish for breeding by hormonal stimulation. Only those females containing the highest percentage of mature oocytes having germinal vesicle in the centre or initial stage of migration were selected for the hormone treatment (Billard et al. 1984).

In total, 12 matured females and 24 male fish weighing from 50 to $90 \mathrm{~g}$ were randomly selected for three hormonal treatment groups and one control group. One day before the experiment, the fish were selected and transferred to 1500 -L concrete tanks $(3 \times 1 \times 1 \mathrm{~m})$ filled with de-chlorinated water to the depth of $50 \mathrm{~cm}$. Each breeding set consisted of two males and one female (Haniffa et al. 1996). The selected fish were injected intramuscularly either with saline $(0.9 \% \mathrm{NaCl}$, control group) or with Ovatide at 0.2 , 0.4 , or $0.6 \mathrm{~mL} \cdot \mathrm{kg}^{-1}$ body weight (BW), respectively. For each dose, three breeding trials were made to find out the differences in response by the fish and to observe the variation in latency period, the rate of fertilization, and percentage of hatching in each treatment groups.

The hormone-treated broodfish were introduced into the cemented breeding tank $(3 \times 1 \times 1 \mathrm{~m})$. Aquatic macrophytes such as Eichhornia crassipes and Hydrilla verticillata were introduced into the breeding tank for performing their breeding activities under hiding condition. After spawning, eggs were collected from the breeding tank, and the number of eggs spawned (spawning fecundity) and rate of fertilization was calculated. Dead eggs were removed from the egg batches by siphoning. Two hours post-spawning, a total of 500 fertilized eggs from each breeding set were collected and incubated in glass aquaria to determine the incubation period and hatching rate. The water quality parameters recorded during the study were as follows, temperature, $29 \pm 1{ }^{\circ} \mathrm{C}$; dissolved oxygen, 5.8-6.5 mg $\cdot \mathrm{L}^{-1}$; and $\mathrm{pH} 7.5-8.1$.

The fertilization and hatching rate were calculated as follows: 
- Fertilization rate $[\%]=$ number of fertilized eggs/total number of eggs counted $\times 100$;

- Hatching rate $(\%)=$ number of eggs hatched/total number of eggs in a batch $\times 100$.

Statistical analysis. The data obtained for mean number of spawning fecundity, fertilization rate, latency period, and hatching rate from each hormone dose were analyzed using one-way analysis of variance (ANOVA) to find significant difference among the hormone doses and each treatment mean were analysed by Duncan's multiple range tests $(P=0.05)$ using SPSS package Version.11.

\section{RESULTS}

The spawning performances of $C$. punctatus induced at different Ovatide doses are presented in Table 1. No spawning behaviour and performance was observed in the control groups. The hormone-induced fish showed breeding behaviour 3-4 $\mathrm{h}$ after injection irrespective of dosages. Each female paired with a single male. At all times, the more active and aggressive male paired with the female while the other one was found to be passive and idle in the corner of the breeding tank. Mating was preceded by elaborate courtship. Spawning rituals commenced after 8-12 h of the hormone injection and continued until the releasing of gametes. Spawning was noticed within 25-30.5 $\mathrm{h}$ after the hormone administration. Minimum latency period was observed for the Ovatide dose of $0.4 \mathrm{~mL} \cdot \mathrm{kg}^{-1} \mathrm{BW}$ but no significant difference $(P>0.05)$ was recognized between the low and high hormone doses of 0.2 and $0.6 \mathrm{~mL} \cdot \mathrm{kg}^{-1} \mathrm{BW}$.
The spawning fecundity (per $\mathrm{g}$ female) in fish that were administered with $0.2,0.4$, and $0.6 \mathrm{~mL} \cdot \mathrm{kg}^{-1} \mathrm{BW}$ of fish were $20 \pm 6,102 \pm 7$, and $39 \pm 4$, respectively. Significantly highest $(P<0.05)$ spawning fecundity was obtained in fish administered with a dose of $0.4 \mathrm{~mL} \cdot \mathrm{kg}^{-1} \mathrm{BW}$, than those with $0.2 \mathrm{~mL} \cdot \mathrm{kg}^{-1}$, and $0.6 \mathrm{~mL} \cdot \mathrm{kg}^{-1} \mathrm{BW}$ doses of Ovatide, respectively. The highest fertilization rate $(90.6 \pm 1.52 \%)$ and hatching rate $(91.33 \pm 2.51 \%)$ observed in the medium dose of $0.4 \mathrm{~mL} \cdot \mathrm{kg}^{-1} \mathrm{BW}$ and were significantly higher than the fish injected with $0.2 \mathrm{~mL} \cdot \mathrm{kg}^{-1}$ and $0.6 \mathrm{~mL} \cdot \mathrm{kg}^{-1} \mathrm{BW}$ (Table 1). Hatching rates were not statistically significant between the doses of $0.4 \mathrm{~mL} \cdot \mathrm{kg}^{-1}$ and $0.6 \mathrm{~mL} \cdot \mathrm{kg}^{-1} \mathrm{BW}$ administered groups. The incubation period ranged from 24 to $28 \mathrm{~h}$ at the water temperatures of $29 \pm 1.5^{\circ} \mathrm{C}$. In the present study, no size differences of larvae were observed, despite the hatching performances varied among the hormone doses tested.

\section{DISCUSSION}

In the present study, a single intramuscular injection of synthetic hormone, Ovatide resulted in successful spawning of Channa punctatus. Table 2 summarizes the results of induced spawning and the success rate of different fish species using Ovatide. To the best of our knowledge, this is the first successful attempt to use Ovatide as a stimulating agent for induced spawning of this commercially-important native threatened fish species in a controlled captive condition. Successful spawning using Ovatide and its analogues has also been reported in several fish species viz., stinging catfish, Heteropneustes fossilis (cf. Marimuthu et al. 2000); snakehead murrel,

Table 1

Induced spawning of Channa punctatus using a synthetic hormone Ovatide

\begin{tabular}{|c|c|c|c|c|c|c|c|c|c|}
\hline \multirow{2}{*}{$\begin{array}{l}\text { Hormone } \\
\text { dose } \\
{[\mathrm{mL} / \mathrm{kg} \mathrm{BW}]}\end{array}$} & \multicolumn{2}{|c|}{ No. of fishes } & \multicolumn{2}{|c|}{ Fish weight $[\mathrm{g}]$} & \multirow{2}{*}{$\begin{array}{c}\text { Latency period } \\
{[\mathrm{h}]}\end{array}$} & \multirow{2}{*}{$\begin{array}{c}\text { Total spawning } \\
\text { fecundity }\end{array}$} & \multirow{2}{*}{$\begin{array}{c}\text { Spawning } \\
\text { fecundity } \\
\text { [Eggs/g } \\
\text { female BW] }\end{array}$} & \multirow{2}{*}{$\begin{array}{c}\text { Fertilization } \\
\text { rate }[\%]\end{array}$} & \multirow{2}{*}{$\begin{array}{l}\text { Hatching } \\
\text { rate }[\%]\end{array}$} \\
\hline & male & female & male & female & & & & & \\
\hline Control & 6 & 3 & $72.6 \pm 5.35^{\text {a }}$ & $53.00 \pm 2.6^{\mathrm{a}}$ & - & - & - & - & - \\
\hline 0.2 & 6 & 3 & $69.8 \pm 5.38^{a}$ & $53.33 \pm 5.7^{\mathrm{a}}$ & $30.5 \pm 1.3^{\mathrm{b}}$ & $1080 \pm 235^{\mathrm{c}}$ & $20 \pm 6^{c}$ & $74.0 \pm 3.0^{c}$ & $82.6 \pm 5.13^{t}$ \\
\hline 0.4 & 6 & 3 & $72.6 \pm 5.16^{\mathrm{a}}$ & $56.66 \pm 3.0^{\mathrm{a}}$ & $25.0 \pm 0.7^{\mathrm{a}}$ & $5814 \pm 556^{a}$ & $102 \pm 7^{\mathrm{a}}$ & $90.6 \pm 1.52^{\mathrm{a}}$ & $91.33 \pm 2.51$ \\
\hline 0.6 & 6 & 3 & $70.0 \pm 5.21^{\mathrm{a}}$ & $53.66 \pm 0.5^{a}$ & $29.1 \pm 1.2^{\mathrm{b}}$ & $2108 \pm 214^{b}$ & $39 \pm 4^{b}$ & $81.6 \pm 3.78^{b}$ & $88.0 \pm 3.60$ \\
\hline
\end{tabular}

Values in each column with same letter are not statistically different $(P>0.05)$.

Table 2

Comparative account on induced breeding by Ovatide in different fish species in India

\begin{tabular}{lccc}
\hline Species & $\begin{array}{c}\text { Ovatide dose } \\
{\left[\mathrm{mL} \cdot \mathrm{kg}^{-1} \mathrm{BW}\right]}\end{array}$ & $\begin{array}{c}\text { Latency period } \\
{[\mathrm{h}]}\end{array}$ & Reference \\
\hline Catla, Gibelion catla & $0.2-0.5$ & 7.4 & Thakur and Reddy (1997) \\
Mirgal, Cirrhinus mrigala & $0.2-0.4$ & 9.32 & Thakur and Reddy (1997) \\
Grass carp, Ctenopharyngodon idella & $0.2-0.65$ & 10.5 & Thakur and Reddy (1997) \\
Orange-fin labeo, Labeo calbasu & $0.3-0.5$ & 6.0 & Thakur and Reddy (1997) \\
Rohu, Labeo rohita & $0.2-0.4$ & 8.45 & Thakur and Reddy (1997) \\
Stinging catfish, Heteropneustes fossilis & 0.4 & 10.0 & Marimuthu et al. (2000) \\
Java barb, Puntius javanicus & $0.3-0.6$ & 8.0 & Thakur and Reddy (1997) \\
Snakehead murrel, Channa striatus & 0.4 & 24.0 & Marimuthu and Haniffa (2007) \\
\hline
\end{tabular}


Channa striatus (cf. Marimuthu et al. 2007); narrowfront tandan, Neosilurus ater (cf. Cheah and Lee 2000); and in several cyprinid species, like common carp, Cyprinus carpio; silver carp, Hypophthalmichthys molitrix; and tench, Tinca tinca (cf. Horváth et al. 1997).

The latency period of $C$. punctatus ranged from 25 to $31 \mathrm{~h}$ at $29 \pm 1.5^{\circ} \mathrm{C}$ in the three doses tested. The latency period was longer than those reported in $H$. fossilis administered with Ovatide (Marimuthu et al. 2000) but it was similar to those in C. striatus using Ovaprim (Haniffa et al. 1996) and in C. striatus using Ovatide (Marimuthu et al. 2007). In contrast, short latency periods using Ovatide ranged between 7 and $10.5 \mathrm{~h}$ in different carp species have been reported (Table 2). The latency period is related to water temperature and often decreases with an increase in temperature (Clemens and Sneed 1962).

In the present experiment, complete spawning was observed at the Ovatide doses of $0.4 \mathrm{~mL} \cdot \mathrm{kg}^{-1}$ and $0.6 \mathrm{~mL} \cdot \mathrm{kg}^{-1} \mathrm{BW}$ whereas the dose of $0.2 \mathrm{~mL} \cdot \mathrm{kg}^{-1} \mathrm{BW}$ induced partial spawning. Complete spawning has been reported using Ovatide in carps (Thakur and Reddy 1997), in pabo catfish, (Mukherjee and Das 2001), and stinging catfish (Marimuthu et al. 2000). The highest hatching rate was observed in the dose of $0.4 \mathrm{~mL} \cdot \mathrm{kg}^{-1} \mathrm{BW}$. However, the overall hatching rates of Ovatide-treated fish were high compared to those reported in the same fish species using pituitary extract (Parameshwaran and Murugesan 1976). Similar results were also observed in other air breathing fishes, $C$. striatus and $H$. fossilis (cf. Marimuthu et al. 2000, 2007). In general, the response of fish to Ovatide was found to be better, considering the spawning success, number of released eggs, and, percentages of fertilization and hatching. Further, the synthetic hormones like Ovaprim and Ovatide are known to act at the pituitary level leading to the secretion of fish's own endogenous gonadotropins, while in the case of hypophysation technique and administration of HCG exogenous gonadotropins, they are directly delivered into the body (Habibi et al. 1989, Zairin et al. 1992, Goswami and Sharma 1997). Endogenous gonadotropins appear to significantly enhance the secretion of the right type of steroids in abundant quantity enabling complete maturity of ova for spawning. The results of the present investigation demonstrate the possibility of using the synthetic hormone, Ovatide at a dose of $0.4 \mathrm{~mL} \cdot \mathrm{kg}^{-1} \mathrm{BW}$ for induced spawning and will be appropriate for mass seed production of Channa punctatus. Low and higher doses are reported to affect the egg quality, lead to partial spawning or reduced fertilization and hatching rate. The new ovulating agent, Ovatide is less expensive, easy to store, simple to use, and has lower viscosity compared to Ovaprim and other hormones used for fish breeding in the aquaculture sector. If Ovatide is made locally available at a competitive low price, it could be used as the first alternate to the high-priced Ovaprim for successful breeding of $C$. punctatus including other commercial fish species by the hatchery operators and seed producers in their aquaculture farms. On the other hand, this study represents the first successful attempt to propagate C. punctatus using synthetic Ovatide as a stimulating agent. Therefore, the findings emerge from the present study would immensely be helpful for quality seed production in snakehead and other threatened freshwater fishes as well as for their conservation and rehabilitation. Further studies are required to examine the development and growth performances of larvae and fry produced by propagation with Ovatide.

\section{ACKNOWLEDGEMENTS}

The authors are thankful to Principal, St. Xavier's College, Palayamkottai, for providing necessary facilities for this research and Department of Science and Technology, New Delhi for providing fellowship to the first author.

\section{REFERENCES}

Billard R., Reinaud P., Hollebecq M.G., Breton B. 1984. Advancement and synchronisation of spawning in Salmo gairdneri and S. trutta following administration of LRH-A combined or not with pimozide. Aquaculture 43: 57-66. DOI: 10.1016/0044-8486(84)90009-7.

Brzuska E. 2001. Artificial spawning of European catfish Silurus glanis L.: differences between propagation results after stimulation of ovulation with carp pituitary and Ovopel. Aquaculture Research 32: 11-19. DOI: 10.1111/ /j.1365-2109.2001.00520.x.

Brzuska E. 2003.Artificial propagation of African catfish (Clarias gariepinus): differences between reproduction effects after stimulation of ovulation with carp pituitary homogenate or GnRH-a and dopaminergic inhibitor. Czech Journal of Animal Science 48: 181-190.

Brzuska E. 2006. Artificial propagation of female Hungarian strain 7 carp (Cyprinus carpio) after treatment with carp pituitary homogenate, Ovopel or Dagin. Czech Journal of Animal Science 51: 132-141.

Cheah M.S.H., Lee C.L. 2000. Induced ovulation of the Australian eel-tailed catfish Neosilurus ater (Perugia) with Ovaprim. Asian Fisheries Science 13: 87-96.

Clemens H.P., Sneed K.E. 1962. Bioassay and use of pituitary materials to spawn warm water fishes. US Fish and Wildlife Service Research Report No. 61. Washington DC.

Das S.K. 2004. Evaluation of a new spawning agent, Ovopel in induced breeding of Indian carps. Asian Fisheries Science 17: $313-322$.

Goswami U.G., Sharma N.N. 1997. Pituitary dose optimization for induced ovulation, in vitro fertilization and production of normal fry of Clarias batrachus (Linn). Asian Fisheries Science 10: 163-167.

Habibi H.R., Marchant T.A., Nahorniak C.S., Van der Loo H., Peter R.E., Rivier J.E., Vale W.W. 1989. Functional relationship between receptor binding and biological activity for analogs of mammalian and salmon gonadotropinreleasing hormones in the pituitary of goldfish (Carassius auratus). Biology of Reproduction 40: 1152-1161.

Haniffa M.A., Marimuthu K., Nagarajan M., Arokiaraj A.J., Kumar D. 2004. Breeding behaviour and parental care of 
the induced bred spotted murrel Channa punctatus under captivity. Current Science 86: 1375-1376.

Haniffa M.A., Shaik Mohammed J., Merlin Rose T. 1996. Induction of ovulation in Channa striatus (Bloch) by SgnRHa. Fishing Chimes 16 (5): 23-24.

Horváth L., Szabó T., Burke J. 1997. Hatchery testing of GnRH analogue-containing pellets on ovulation in four cyprinid species. Polskie Archiwum Hydrobiologii 44: 221-226.

Marimuthu K., Kumar D., Haniffa M.A. 2007. Induced spawning of striped snakehead, Channa striatus, using Ovatide. Journal of Applied Aquaculture 19 (4): 95-103. DOI: 10.1300/J028v19n04_06

Marimuthu K., Muruganandam M., Haniffa M.A. 2000. Induced spawning of the Indian catfish Heteropneustes fossilis (Singhi) using a synthetic hormone, Ovatide. Fishing Chimes 19 (10-11): 105-106.

Molur S., Walker S. 1998. Report of the workshop on "Conservation Assessment and Management Plan (CAMP) for freshwater fishes of India"; Lucknow, 22-26 September 1997. Organised by Zoo Outreach Organisation and NBFGR.

Mukherjee M., Das S. 2001. Artificial propagation of a silurid fish pabda Ompok pabo (Hamilton). Fishing Chimes 21: $75-79$.

Munro A.D. 1990. General introduction. Pp. 1-11. In: Munro A.D., Scott A.R., Lam T.J., (eds.) Reproductive seasonality in teleosts: environmental influences. CRC Press, Boca Raton FL.

Parameshwaran S., Murugesan V.K. 1976 Observation on the hypophysation of murrels (Ophiocephalidae). Hydrobiologia 50: 81-87.
Peter R.E., Lin H.-R., Van der Kraak G. 1988. Induced ovulation and spawning of cultured freshwater fish in China: advances in application of GnRH analogues and dopamine antagonists. Aquaculture 74: 1-10. DOI:10.1016/00448486(88)90080-4.

Peter R.E., Yu K.L. 1997. Neuroendocrine regulation of ovulation in fishes: basic and applied aspects. Reviews in Fish Biology and Fisheries 7: 173-197. DOI: 10.1023/ /A:1018431610220.

Sahoo S.K., Giri S.S., Sahu A.K. 2005. Effect on breeding performance and egg quality of Clarias batrachus (Linn.) at various doses of Ovatide during spawning induction. Asian Fisheries Science 18: 77-83.

Thakur N.K., Reddy A.K. 1997. Repeat field trials with new hormonal preparation-Ovatide for fish breeding. Final Report, CIFE, Mumbai, India.

Yaron Z. 1995. Endocrine control of gametogenesis and spawning induction in the carp. Aquaculture 129: 49-73. DOI: 10.1016/0044-8486(94)00229-H.

Zairin M., Furukawa K., Aida K. 1992. Induction of ovulation by HCG injection in the tropical walking catfish Clarias batrachus reared under $23-25^{\circ} \mathrm{C}$. Nippon Suisan Gakkaishi. 58: $1681-1685$.

Zohar Y., Mylonas C.C. 2001. Endocrine manipulations of spawning in cultured fish: from hormones to genes. Aquaculture 197: 99-136. DOI: 10.1016/S0044$-8486(01) 00584-1$.

Received: 18 June 2008 Accepted: 10 December 2008 Published electronically: 20 May 2009 